\title{
PERUBAHAN STATUS PENERIMA LISENSI TERHADAP PERJANJIAN LISENSI HAK CIPTA
}

\author{
Lailatusafa'ah Indrasrani \\ Universitas Diponegoro Semarang \\ email : $\underline{\text { ilaindrasrani@gmail.com }}$
}

\begin{abstract}
ABSTRAK
Hak cipta adalah hak eksklusif atau yang hanya dimiliki si Pencipta atau Pemegang Hak Cipta untuk mengatur penggunaan hasil karya atau hasil olah gagasan atau informasi tertentu. Pencipta itu dapat mengalihkan haknya kepada pihak lain. Biasanya hal itu dilakukan sesudah suatu perembukan dan tercapai kata sepakat. Lalu diharuskan membuat akta surat perjanjian yang disebut perjanjian lisensi. Perjanjian lisensi (licensing agreement) merupakan perjanjian antara pemberi lisensi (licensor) dengan penerima lisensi (licensee). Licensor memberikan izin kepada licensee untuk menggunakan HKI miliknya dan sebagai imbalannya licensor mendapatkan royalti dari licensee. Perjanjian dapat menjadi kabur apabila terdapat perubahan identitas pada salah satu pihak yang terdapat dalam perjanjian lisensi tersebut.
\end{abstract}

Kata kunci : Hak Cipta, Perjanjian Lisensi, Perubahan Status

\begin{abstract}
Property rights that are transferrable to other parties would normally follow mutual understanding of both parties and are legally bound under the license agreement. The accord is signed by the respective licensor and licensee. Under this accord, the licensor gives permission to a licensee to make use of it with royalty paid off to the licensor. The study employs is normative approach. The paper discusses elements to be incorporated into the agreement according to the Law described at the Chapter 1320 KUHPdt. It is our finding that the agrrement is legally bound whenever all the elements required by the Law are fulfilled.
\end{abstract}

Key words : Property Rights, License agreement, change of status

\section{A. Pendahuluan}

Manusia itu dikaruniai oleh Tuhan Yang Maha Esa dengan berbagai naluri, bakat, nilai, dan kemampuan untuk hidup menurut pola tertentu. Curahan isi pikiran dan hati nurani itu dinamakan ciptaan. Setiap manusia dimuka bumi ini memiliki hak mutlak atas hasil kreasi yang telah diciptakan atau telah mereka wujudkan dalam bentuk barang maupun dalam bentuk ide. Hak mutlak yang dimiliki karena setiap hasil kreasi dari pikiran manusia itulah yang disebut dengan hak cipta, yaitu 
hak yang langsung dimiliki oleh seseorang setelah ia berhasil mewujudkan hasil kreasi yang ada di pikirannya dalam bentuk ide-ide, gagasan maupun barang.

Penentuan siapa pencipta atau pemegang hak cipta dari suatu ciptaan tentunya menimbulkan hak bagi pihak yang ditetapkan sebagai pencipta atau pemegang hak cipta, yaitu hak moral dan hak ekonomi. Tak jarang konflik timbul akibat dari perjanjian lisensi yang dari waktu ke waktu dapat mengalami perubahan karena hal - hal yang ditimbulkan baik oleh pencipta itu sendiri, pemegang hak cipta maupun pihak lain diluar dari apa yang tertulis dalam perjanjian lisensi. Adanya ketidakjelasan dalam perjanjian lisensi dapat memungkinkan adanya penyalahgunaan hak cipta yang selanjutnya dapat menimbulkan konflik antara pencipta dengan pihak lain baik pemegang hak cipta ataupun pihak yang tidak berhak untuk menggunakan hak cipta tersebut.

Penyelesaian sengketa hak cipta dapat dilakukan melalui alternatif penyelesaian sengketa, arbitrase, atau pengadilan. Pengadilan yang berwenang adalah pengadilan niaga. Pengadilan lainnya selain pengadilan niaga tidak berwenang menangani penyelesaian sengketa hak cipta.

Sengketa mengenai siapa pemegang hak cipta dari suatu ciptaan yang terjadi di Indonesia, sebagai contoh salah satunya mengenai kasus sengketa logo organisasi Konfederasi Serikat Buruh Sejahtera Indonesia (KSBSI) antara Muchtar Pakpahan melawan Rekson Silaban. Dr. Muchtar Pakpahan, S.H, M.A adalah Pendiri, deklarator dan mantan Ketua Umum SBSI (Serikat Buruh Sejahtera Indonesia) yang kini menjadi Konfederasi Serikat Buruh Sejahtera Indonesia (KSBI).

Pada kongres keempat (IV), para peserta kongres memutuskan untuk merubah bentuk organisasi yang sebelumnya berbentuk organisasi Unitaris menjadi Konfederasi atau Dewan Pengurus Pusat Konfederasi Serikat Buruh Sejahtera Indonesia (DPP KSBSI) yang merupakan organisasi payung, memiliki 11 (sebelah) Federasi Serikat Buruh. Adanya perubahan inilah yang membuat perjanjian lisensi antara pencipta dan pemegang lisensi menjadi tidak jelas, karena pencipta menganggap ia menyerahkan lisensi hak cipta kepada SBSI bukan KSBSI.

Hak Kekayaan Intelektual ("HKI") atau secara universal dikenal juga dengan sebutan Intelectual Property Right ("IPR") berkembang secara pesat baik di dunia maupun di Indonesia. HKI memiliki 3 unsur yang penting yaitu hak, manusia, dan intelektual. HKI merupakan hak kebendaan immateriil atau hak atas benda tidak berwujud yang lahir atas kemampuan intelektual manusia berupa hasil kerja kecerdasan intelegensia dan kecerdasan emosional. Intelegensia dan kecerdasan emosional telah melahirkan banyak karya cipta mulai dari karya berupa ilmu pengetahuan dan seni meliputi patung, buku, ceramah, drama, musik, rekaman suara, ciptaan audio visual, seni tari, fotografi, sinematografi, terjemahan dan lainlain yang kemudian dilindungi sebagai hak cipta, dan produk yang dibuat oleh pencipta tersebut disebut ciptaan (Agus Sardjono, 2009 : 137).

Nilai ekonomi yang melekat menumbuhkan konsepsi kekayaan (property) terhadap karya - karya intelektual tadi. Perjanjian internasional TRIPs agreement menetapkan hak cipta sebagai bagian dari Hak kekayaan intelektual. Hak cipta adalah suatu rezim hukum yang dimaksudkan untuk melindungi para pecipta agar mereka dapat memperoleh manfaat ekonomi atas hasil karya ciptanya. 
Hak Cipta diatur dalam UU No. 28 Tahun 2014 tentang Hak Cipta (UUHC). Pasal 1 angka 1 UUHC, menyebutkan bahwa:

Hak cipta adalah hak eksklusif pencipta yang timbul secara otomatis berdasarkan prinsip deklaratif setelah suatu ciptaan diwujudkan dalam bentuk nyata tanpa mengurangi pembatasan sesuai dengan ketentuan peraturan perundang - undangan.

Dengan demikian pemegang hak cipta memiliki hak eksklusif untuk mengumumkan atau memperbanyak ciptaannya, baik secara sendiri maupun bersama dengan pihak lain. Selain itu, ia juga berhak memberikan izin kepada pihak lain untuk mengumumkan atau memperbanyak ciptaannya.

Dalam Auteurswet 1912 maupun Universal Copyright Convention menggunakan istilah "hak tunggal" sedangkan dalam Undang-undang Hak Cipta menggunakan istilah "hak eksklusif atau hak khusus". Yang dimaksudkan dalam "hak eksklusif atau hak khusus" adalah pencipta merupakan satu-satunya pihak yang dapat memanfaatkan hak tersebut. Dengan kata lain tidak ada pihak lain yang dapat memanfaatkan hak tersebut kecuali dengan izin pencipta.

Perkataan "tidak ada pihak lain" mempunyai pengertian yang sama dengan hak tunggal yang menunjukkan hak pencipta saja yang dapat mendapatkan hak semacam itu. Inilah yang kemudian disebut dengan hak eksklusif/hak khusus. Eksklusif berarti khusus, spesifikasi, unik (OK Saididn, 2010 : 59).

Pencipta itu dapat mengalihkan haknya kepada seseorang atau kepada suatu lembaga, badan atau perusahaan untuk memanfaatkannya, mengumumkan, memperbanyak, atau menyiarkannya. Ini dinamakan pemegang atau pemakai hak cipta. Biasanya hal itu dilakukan sesudah suatu perembukan dan tercapai kata sepakat. Lalu diharuskan membuat akta surat perjanjian. Isinya sesuai dengan kata sepakat antara pencipta dan penerima hak, jadi timbul ikatan hukum diantara mereka yang menuntut dari kedua belah pihak, kesetiaan serta kejujuran satu sama lain dalam pelaksanaannya (Hutauruk, $1982: 11$ ).

Hak kekayaan intelektual mempunyai manfaat ekonomi yang cukup tinggi. Atas dasar perjanjian, pencipta dapat memberikan izin untuk menikmati manfaat ekonomi kekayaan intelektual yang dimilikinya kepada pihak lain. Undang undang memberikan kesempatan kepada pencipta yang mempunyai aset HKI untuk menggunakan hak atas aset HKI yang dimilikinya kepada pihak lain yaitu penggunaan HKI berdasarkan suatu perjanjian lisensi (Etty Susilowati, 2012 : 137 138).

Perjanjian lisensi (licensing agreement) merupakan perjanjian antara pemberi lisensi (licensor) dengan penerima lisensi (licensee). Licensor memberikan izin kepada licensee untuk menggunakan HKI miliknya untuk memproduksi, mendistribusikan, dan memasarkan produk-produk milik licensor, dan sebagai imbalannya licensor mendapatkan royalti dari licensee. HKI yang diberikan lisensinya dapat berupa hak cipta, merek, paten, rahasia dagang, dan lain-lain.

Perjanjian lisensi dapat berskala nasional maupun internasional. Dalam skala internasional, pemberian lisensi HKI pada perusahaan di luar negeri merupakan salah satu bentuk perdagangan internasional yang bertujuan untuk memperluas pasar di luar negeri. Bentuk perdagangan semacam ini banyak dijumpai 
di Indonesia, di mana perusahaan asing memberikan lisensi HKI kepada perusahaan nasional untuk memproduksi, mendistribusikan, dan memasarkan produk-produknya di Indonesia.

Lisensi yang berasal dari kata latin "Licentia" memberikan definisi bahwa dengan lisensi, memberikan kebebasan atau izin kepada seseorang untuk menggunakan sesuatu yang sebelumnya tidak boleh digunakan oleh pihak lain (Ruslan Shaleh, $1991: 11$ ).

Lisensi dalam pengertian lebih lanjut senantiasa melibatkan suatu bentuk perjanjian tertulis dari pemberi lisensi dan penerima lisensi. Perjanjian ini sekaligus berfungsi sebagai bukti pemberian izin dari pemberi lisensi kepada penerima lisensi untuk menggunakan nama dagang, paten, atau hak milik lainnya (HKI). Pemberian hak untuk memanfaatkan Hak atas Kekayaan Intelektual ini disertai dengan imbalan dalam bentuk pembayaran royalti oleh penerima lisensi kepada pemberi lisensi (Gunawan, 2011 : 9).

Sengketa mengenai Hak kekayaan intelektual khususnya bidang Hak Cipta tak terhindarkan. Biasanya sengketa tersebut berkisar pada masalah yang bersinggungan dengan pendaftaran hak cipta, yang biasanya berkaitan dengan siapa pencipta atau pemegang hak cipta dari ciptaan tersebut. Pencipta adalah pemegang hak cipta atas ciptaannya sementara pemegang hak cipta adalah pencipta itu sendiri sebagai pemilik Hak Cipta atau orang yang menerima hak tersebut dari Pencipta, atau orang lain yang menerima lebih lanjut hak dari orang tersebut (Tim Lindsey, 2006 : 110).

Berdasarkan uraian kasus yang telah dibahas didepan tadi dapat kita lihat bahwa antara pencipta dan pemegang hak cipta terdapat suatu perjanjian atau ikatan dalam hal hak dan kewajiban. Didalam Kitab Undang - Undang Hukum perdata pasal 1313 menyatakan bahwa "Suatu perjanjian adalah suatu perbuatan dimana satu orang atau lebih mengikatkan diri pada satu orang atau lebih".

Dengan kata lain perjanjian adalah suatu perbuatan yang dilakukan antara sekurang - kurangnya dua orang (atau lebih) dimana perbuatan tersebut melahirkan perikatan diantara pihak - pihak yang berjanji tersebut. Dalam Kitab Undang Undang Hukum perdata juga dijelaskan mengenai asas - asas umum perjanjian, diantaranya Asas Konsensualisme (Pasal 1320), Asas Pacta Sun Servanda (Pasal 1338 ayat (1) dan (2), Asas Kebebasan Berkontrak (Pasal 1320), dan Asas Itikad Baik (Pasal 1338 ayat (3)). Dalam kaitannya dengan kasus diatas Asas Konsensualisme dan Asas Pacta Sun Servanda merupakan asas yang paling berpengaruh. Asas Konsensualisme mempunyai pengertian bahwa suatu perjanjian yang dibuat oleh para pihak itu akan mengikat para pihak ketika mencapai kata sepakat, walaupun kesepakan itu terjadi secara lisan. Pada hakikatnya suatu suatu perjanjian itu tidak membutuhkan formalitas, tapi untuk kepentingan dari pihak debitor, dalam hal hal tertentu diadakan bentuk-bentuk formalitas, mengantisipasi suatu tindakan yang diluar dari pada itu.

Sedangkan Asas Pacta Sun Servanda dalam Pasal 1338 ayat (1) dan ayat (2) KUH Perdata yang menyatakan "semua perjanjian yang dibuat secara sah berlaku sebagai undang-undang bagi mereka yang membuatnya". Dalam kasus diatas karena adanya perubahan nama dan status organisasi oleh salah satu pihak dalam perjanjian 
maka menjadi tidak jelas apakah perubahan tersebut berpengaruh terhadap keberlangsungan hak dan kewajiban yang sudah disepakati dalam perjanjian lisensi.

Berdasarkan Undang - Undang Republik Indonesia Nomor 28 tahun 2014 tentang Hak Cipta dalam pasal 1 angka 20 memberikan pengertian Lisensi adalah izin tertulis yang diberikan oleh Pemegang Hak Cipta atau Pemilik Hak Terkait kepada pihak lain untuk melaksanakan hak ekonomi atas ciptaanya atau produk Hak Terkait dengan syarat tertentu.

Selain hak moral sebagai bentuk pengakuan, hak ekonomi juga merupakan suatu tujuan karena dengan hak tersebut satu pihak bisa mendapatkan keuntungan daripada ciptaannya. Salah satu cara untuk mendapatkan keuntungan tersebut bisa dengan cara perjanjian lisensi.

\section{B. Rumusan Masalah}

Apakah setiap perubahan status penerima lisensi membawa implikasi terhadap keberlanjutan perjanjian lisensi hak cipta?

\section{Hasil dan Pembahasan \\ 1. Pengertian Hak Cipta}

Sejalan dengan hak cipta sebagai hak eksklusif dan hak ekonomi, pihak pencipta/ pemegang hak cipta mempunyai hak untuk memberi izin kepada pihak lain untuk melaksanakan hak ekonomi atas ciptaannya dan pemberian izin tersebut tidak dapat dilepaskan dari masalah keuntungan dari penggunaan hak cipta. Pemberian izin dari pencipta/ pemegang hak cipta kepada orang lain itulah yang disebut dengan lisensi (Gatot Supramono, $2010: 37$ ).

Mengenai pemindahtanganan hak cipta bahwa benda ini dapat beralih atau dialihkan oleh pemegangnya. Berdasarkan Pasal 16 ayat (2) Undang-Undang Hak Cipta 2014 telah diatur tentang hal tersebut, bahwa hak cipta dapat beralih atau dialihkan baik sebagian atau seluruhnya karena: pewarisan, hibah, wakaf, wasiat, perjanjian tertulis, atau sebab lain yang dibenarkan sesuai dengan ketentuan peraturan perundang-undangan.

Salah satu cara pemindahan Hak cipta adalah melalui perjanjian tertulis. Bentuk perjanjian yang dimaksud dalam Undang-undang Hak Cipta 2014 cenderung kepada perjanjian yang timbal balik dimana kedua belah pihak yang melakukan perjanjian mampunyai hak-hak dan kewajiban-kewajiban yang saling bertimbal balik antara yang satu dengan yang lainnya. Bentuk perjanjiannya dapat berupa perjanjian jual beli atau perjanjian tukar menukar. Pemegang hak cipta dapat menjual hak ciptanya kepada orang lain, atau menukarkan hak ciptanya dengan barang yang lain. Kedua perjanjian tersebut berakibat beralihnya hak milik atas suatu benda (Gatot, $2010: 35$ ).

Berdasarkanpenjelasan sebelumnya, orang selain pencipta dapat menikmati hak tersebut dari seorang pencipta dengan cara pengalihan hak cipta. Pasal 16 ayat (2) UU Hak Cipta hak cipta dapat beralih atau dialihkan, baik seluruh maupun sebagian karena: (Aditya, Vol $1: 35$ ).
a) pewarisan;
b) hibah;
c) wakaf; 
d) wasiat;

e) perjanjian tertulis; atau

f) sebab lain yang dibenarkan sesuai dengan ketentuan peraturan perundangundangan.

Hak ekonomi atas suatu hak cipta dapat dialihkan, namun Pasal 5 ayat (2) UUHC, hak moral tidak dapat dialihkan selama Pencipta masih hidup, tetapi pelaksanaan hak tersebut dapat dialihkan dengan wasiat atau sebab lain sesuai dengan ketentuan peraturan perundang-undangan setelah pencipta meninggal dunia.

Intellectual property rights atau hak atas kekayaan intelektual memiliki ciri khas yakni bernilai komersial dan merupakan hak pribadi yang dapat dilisensikan dan merupakan hak monopoli guna mencegah orang lain menggunakannya secara tanpa izin (Endang Purwaningsih, 2005 : 2003).

Pemberian izin penggunaan karya dapat dilakukan melalui pemberian lisensi. Lisensi menurut Pasal 1 angka 20 UUHC adalah izin tertulis yang diberikan oleh pemegang hak cipta atau pemilik hak terkait kepada pihak lain untuk melaksanakan hak ekonomi atas ciptaannya atau produk hak terkait dengan syarat tertentu.

Pasal tersebut dapat dipahami bahwa sesungguhnya lisensi adalah suatu izin tertulis yang dapat diberikan satu pihak ke pihak lain untuk melaksanakan suatu hak ekonomi atas ciptaan atau produk hak terkait dengan syarat tertentu. Syarat tertentu mengenai lisensi diatur dalam undang-undang maupun diatur dalam perjanjian lisensi antara licensor (pencipta) dengan licensee (penerima/ hak cipta).

Selain pada hak cipta, lisensi juga diatur dalam bidang HKI yang lain, seperti Rahasia Dagang, Desain Industri, Desain Tata Letak Sirkuit Terpadu, Paten, Merek, dan Hak Cipta.

\section{Tinjauan Umum Perjanjian Lisensi}

Pada dasarnya lisensi di bidang Hak Kekayaan Intelektual tidak sematamata hanya sekedar perbuatan pemberian izin saja, akan tetapi perbuatan tersebut menimbulkan hak-hak dan kewajiban-kewajiban yang saling timbal balik antara pihak satu dengan pihak lain. Atas hal tersebut maka lisensi merupakan perjanjian yang mengikat mereka. Dalam ilmu hukum perjanjian yang demikian disebut perjanjian obligatoire.

Perjanjian lisensi hak cipta juga merupakan perjanjian konsensualisme, karena terjadinya perjanjian itu dilandasi dengan sebuah konsensus atau kata sepakat.

Kemudian lahirnya perjanjian lisensi hak cipta mengikuti asas kebebasan berkontrak, bahwa setiap orang dapat membuat perjanjian apa saja, kapan saja, dan berisi apa saja asal tidak bertentangan dengan hukum, kebiasaan, dan kepatutan. Batasan-batasan yang diberikan Undang-Undang Nomor 28 Tahun 2014 tentang Hak Cipta terhadap kebebasan dalam melakukan perjanjian lisensi adalah seperti yang disebutkan dalam Pasal 82 bahwa: perjanjian lisensi dilarang memuat ketentuan yang mengakibatkan kerugian perekonomian Indonesia; isi perjanjian lisensi dilarang bertentangan dengan ketentuan peraturan perundang-undangan; 
perjanjian lisensi dilarang menjadi sarana untuk menghilangkan atau mengambilalih seluruh hak pencipta atas ciptaannya.

Dalam Pasal 80 Undang-Undang Hak Cipta 2014 disebutkan, bahwa lisensi hak cipta dibuat dengan dasar perjanjian. Karena bentuknya berupa perjanjian maka untuk syarat sahnya suatu perjanjian diatur dalam Pasal 1320 KUH Perdata yang mengemukakan empat syarat,yaitu :

1. Adanya kesepakatan kedua belah pihak

2. Kecakapan untuk melakukan perbuatan hukum

3. Adanya suatu hal tertentu.

4. Adanya sebab yang halal.

Kedua syarat yang pertama disebut syarat subjektif karena kedua syarat tersebut mengenai subjek perjanjian sedangkan dua syarat terakhir merupakan syarat objektif karena mengenai objek dari perjanjian.

Persetujuan tersebut harus bebas, tidak ada paksaan. Kemauan yang bebas sebagai syarat pertama untuk terjadinya perjanjian yang sah. Dianggap perjanjian tersebut tidak sah apabila terjadi karena paksaan, kekhilafan atau penipuan. Sebagaimana dinyatakan dalam Pasal 1321 KUH Perdata yang menyatakan jika di dalam perjanjian terdapat kekhilafan, paksaan atau penipuan, maka berarti di dalam perjanjian itu terjadi cacat kehendak dan karena itu perjanjian tersebut dapat dibatalkan. Cacat kehendak artinya "bahwa salah satu pihak sebenarnya tidak menghendaki isi perjanjian yang demikian. Seseorang dikatakan telah membuat kontrak secara khilaf manakala dia ketika membuat kontrak tersebut dipengaruhi oleh pandangan atau kesan yang ternyata tidak benar (H.R. Daeng Naja, 2006 : 86).

Keempat syarat tersebut haruslah dipenuhi oleh para pihak dan apabila syarat-syarat sahnya perjanjian tersebut telah terpenuhi, maka menurut Pasal 1338 KUH Perdata, perjanjian tersebut mempunyai kekuatan hukum sama dengan kekuatan suatu Undang-undang.

\section{Tinjauan Syarat Sah Perjanjian Dalam KUH Perdata}

Hubungan antara Pasal 1320 KUHPerdata dan Pasal 1338 KUHPerdata dalam perjanjian.

Menurut Pasal 1338 ayat (1) bahwa : Perjanjian yang mengikat hanyalah perjanjian yang sah. Supaya sah pembuatan perjanjian harus mempedomani Pasal 1320 KUHPerdata. Oleh karena itu kedua pasal dalam KUHPerdata tersebut saling mempunyai hubungan yang erat dalam perjanjian / perikatan.

Dari Pasal 1320 KUHPerdata dan Pasal 1338 KUHPerdata tersebut terdapat beberapa hubungan atau azas-azas atau bisa dikatakan juga prinsip-prinsip yang berlaku dalam perjanjian jual beli diantaranya adalah (Marriam, 1997 : 116)

- Asas Kebebasan berkontrak/keterbukaan

- Asas Itikad Baik

- Asas Pacta Sun Servada

- Asas Konsensualitas / Konsensuil (Kesepakatan)

- Asas Berlakunya Suatu Perjanjian

Didalam suatu perjanjian tidak menutup kemungkinan adanya wanprestasi yang dilakukan oleh salah satu pihak dalam perjanjian tersebut yang menimbulkan kerugian kepada salah satu pihak dan dapat menyebabkan batalnya suatu perjanjian. 
Pihak - pihak dalam suatu perjanjian dapat kita sebut dengan kreditur dan debitur. Alasan-alasan yang dapat menimbulkan kebatalan suatu perikatan adalah kalau perikatan tersebut cacat pada syarat-syarat yang objektif saja. Cacat tersebut adalah objek yang melanggar undang-undang dan ketertiban umum.

Hal yang dapat menjadikan kebingungan adalah bagaimana apabila terdapat kesalahan atau perubahan identitas para pihak dalam suatu perjanjian membatalkan suatu perjanjian ? Pasal KUHPerdata mana yang mengaturnya ?

Kesalahan Identitas para pihak dalam suatu perjanjian tidak mutlak menjadikan Perjanjian Itu Batal, asalkan memang klausula dalam perjanjian itu tetap disepakati dan sah menurut hukum. Dalam praktek perjanjian [bisnis], apabila terdapatnya kesalahan identitas maka perjanjian itu bisa diperbaiki, diubah khususnya terhadap Identitas para pihak, tentunya dengan suatu anggapan bahwa para pihak tetap sah dan cakap dalam melakukan tindakan hukum sesuai isi perjanjian(http://www.hukumonline.com/klinik/detail/cl3520/batalnya-suatuperjanjian diakses 18 Mei 2017)

Syarat sahnya suatu perjanjian harus memenuhi ketentuan pasal Pasal 1320 KUHPerdata., yang menyatakan bahwa supaya terjadi persetujuan yang sah, perlu dipenuhi 4 syarat yaitu :

Syarat sahnya perjanjian tersebut terdiri dari:

1.Kesepakatan para pihak dalam perjanjian [agreement]

2.Kecakapan para pihak dalam perjanjian [capacity]

Syarat obyektif :

3.Suatu hal tertentu [certainty of terms]

4.Sebab yang halal [considerations]

Perjanjian dianggap sah dan mengikat secara penuh bagi para pihak yang membuatnya sejauh tidak bertentangan dengan prinsip-prinsip hukum yang berlaku, tidak melanggar kesusilaan dan ketertiban umum. Perjanjian dianggap sah dan mengikat secara penuh bagi para pihak yang membuatnya sejauh tidak bertentangan dengan prinsip-prinsip hukum yang berlaku.

\section{Simpulan}

Syarat sahnya suatu perjanjian harus memenuhi ketentuan pasal Pasal 1320 KUH Perdata., yang menyatakan bahwa supaya terjadi persetujuan yang sah, perlu dipenuhi 4 syarat yaitu : Kesepakatan para pihak dalam perjanjian, Kecakapan para pihak dalam perjanjian, Suatu hal tertentu, Sebab yang halal [considerations]

Kesalahan atau perubahan Identitas para pihak dalam suatu perjanjian tidak mutlak menjadikan Perjanjian Itu Batal, asalkan memang klausula dalam perjanjian itu tetap disepakati dan sah menurut hukum. Dalam praktek perjanjian [bisnis], apabila terdapatnya kesalahan identitas maka perjanjian itu bisa diperbaiki, diubah khususnya terhadap Identitas para pihak, tentunya dengan suatu anggapan bahwa para pihak tetap sah dan cakap dalam melakukan tindakan hukum sesuai isi perjanjian.

Dari uraian di atas, apabila syarat subjektif tidak terpenuhi, maka salah satu pihak dapat meminta supaya perjanjian itu dibatalkan, namun, apabila para pihak tidak ada yang keberatan, maka perjanjian itu tetap dianggap sah. Sementara itu, apabila syarat objektif tidak terpenuhi, maka perjanjian itu batal demi hukum. 
Keempat syarat tersebut haruslah dipenuhi oleh para pihak dan apabila syarat-syarat sahnya perjanjian tersebut telah terpenuhi, maka menurut Pasal 1338 KUH Perdata, perjanjian tersebut mempunyai kekuatan hukum sama dengan kekuatan suatu Undang-undang.

Maka sudah jelas apabila terdapat salah satu pihak yang tidak sepakat dengan perjanjian maka syarat sahnya suatu perjanjian yaitu syarat subjektif tidak terpenuhi, maka salah satu pihak dapat meminta supaya perjanjian itu dibatalkan.

\section{Daftar Pustaka}

\section{Buku :}

Ok, Saidin, 2013, Aspek Hukum Hak Kekayaan Intelektual edisi Revisi, Jakarta: Rajawali Pers.

Sardjono, Agus, 2009, Membumikan HKI di Indonesia, Bandung: CV. Nuansa Aulia.

M, Hutauruk S.H, 1982, Peraturan Hak Cipta Nasional, Jakarta Pusat : Anggota IKAPI, 1982.

Susilowati, Etty, 2012, Hak Kekayaan Intelektual dan Kontrak lisensi HKI, Semarang: Magister Ilmu Hukum Universitas Diponegoro.

Tim Lindsey, Eddy Damian, Simon Butt, Tomi Suryo Utomo, 2006, Hak Kekayaan Intelektual Suatu Pengantar, Bandung : PT. Alumn, 2006.

Shaleh, Ruslan, 1991, Seluk Beluk Praktis Lisensi, Jakarta : Sinar Grafika.

Widjaja, Gunawan, 2011, Seri Hukum Bisnis: Lisensi, Jakarta: Raja Grafindo Persada.

Gunawan, Widjaja, 2011, Seri Hukum Bisnis : Lisensi, Jakarta : Raja Grafindo Persada.

Rahardjo, Satjipto, 2000, Ilmu Hukum, Bandung : PT Citra Aditya Bhakti.

\section{Tesis :}

Heni, Anggraeni, 2015, Tesis, Perlindungan Hukum Bagi Pengguna Lisensi Paten (Licensee) Dalam Rangka Pelaksanaan Alih Teknologi, Semarang : Universitas Diponegoro. 


\section{Jurnal :}

Marbun Tommy Hottua, T. Keizeirina Devi Azwar, dan windha, 2013, Perlindungan Hukum Hak Cipta Terhadap Karya Cipta Lagu Dan Musik Dalam Bentuk Ringtone Dalam Bentuk Ringtone Pada Telepone Seluler. Transparency, Jurnal Hukum Ekonomi, Volume 1 Nomor 1.

Lestari Hesty D, 2013, Kepemilikan Hak Cipta Dalam Perjanjian Lisensi, Jurnal Komisi Yudisial, volume 6, nomor 2. 